\title{
Upaya Peningkatan Pengetahuan tentang Pendidikan Kesehatan Reproduksi dan Seksual Pada Usia Remaja
}

\author{
Ida Baroroh \\ E mail: idamidoren@gmail.com \\ Akademi Kebidanan Harapan Ibu Pekalongan \\ Jl. Sriwijaya No. 7 Pekalongan \\ Telp/Fax (0285)4416108
}

\begin{abstract}
Abstrak
Kesehatan Reproduksi merupakan suatu keadaan sehat secara fisik, mental dan sosial secara utuh, tidak semata-mata bebas dari penyakit atau kecacatan yang berkaitan dengan sistem, fungsi dan proses reproduksi pada laki-laki dan perempuan. Masa Remaja sebagai titik awal proses reproduksi menunjukkan persiapan strategi interfrensi perlu dimulai jauh sebelum masa usia subur. Nilai anak perempuan dan laki-laki dalam keluarga dan masyarakat, dan bagaimana perlakuan yang mereka terima merupakan faktor penting yang turut menentukan kesehatan reproduksi mereka dimasa datang. Tujuan pengabdian masyarakat ini adalah meningkatkan pengetahuan remja tentang pendidikan kesehatan reproduksi dan seksual pada usia remaja. Metode pedidikan kesehatan yang dilakukan yaitu (1) Sosialisasi dan Perijinan, (2) Melakukan Affirmasi dan Pre Test (3) Melakukan Pendidikan kesehatan remaja tentang kesehatan reproduksi dan seksual pada usia remaja. (4) Evaluasi hasil kegiatan pendidikan kesehatan dengan Pre Test. Hasil kegiatan pendidikan kesehatan menunjukkan antusiasme yang baik selama proses pendidikan kesehatan. Antusiasme tersebut ditunjukkan dengan respon peserta yang sangat baik serta kemauan peserta untuk bertanya dan menguraikan pendapatnya. Hasil pendidikan kesehatan ini diharapkan dapat meningkatkan pengetahuan serta pemahaman peserta tentang pentingnya kesehatan reproduksi dan kesehatan seksual pada remaja. Hal ini ditunjukkan dengan hasil kuesioner pre dan post test yang menunjukkan adanya peningkatan pengetahuan tentang pendidikan kesehatan reproduksi dan seksual.
\end{abstract}

Kata kunci: pendidikan kesehatan reproduksi; seksual; remaja.

\begin{abstract}
Reproductive Health is a condition of being physically, mentally and socially healthy as a whole, not only free from diseases or disabilities related to the reproductive system, function and process in men and women. Adolescence as the starting point of the reproductive process shows that the preparation of intervention strategies needs to start long before the fertile age period. The value of girls and boys in the family and society, and how they are treated are important factors that determine their future reproductive health. The aim of this community service is to increase youth knowledge about reproductive and sexual health education at adolescence. Methods of health education are (1) Socialization and Licensing, (2) Conducting Affirmations and Pre Tests (3) Conducting Adolescent Health Education on Reproductive and Sexual Health in Adolescents. (4) Evaluation of the results of health education activities with a Pre Test. The results of health education activities show good enthusiasm during the health education process. This enthusiasm was shown by the excellent response of the participants and the willingness of the participants to ask questions and describe their opinions. The results of this health education are expected to increase participants' knowledge and understanding of the importance of reproductive health and sexual health in adolescents. This is indicated by the results of the pre and post test questionnaires which show an increase in knowledge about reproductive and sexual health education.
\end{abstract}

Keywords: reproductive; sexual; adolescent health education. 


\section{Pendahuluan}

Kesehatan Reproduksi merupakan suatu keadaan sehat secara fisik, mental dan sosial secara utuh, tidak semata-mata bebas dari penyakit atau kecacatan yang berkaitan dengan sistem, fungsi dan proses reproduksi pada laki-laki dan perempuan (UU. RI No 36 Tahun 2009 Pasal 71 ayat 1) ${ }^{1}$ Menurut WHO dan ICPD (International Conference on Population and Development) 1994 yang diselenggarakan di Kairo, Kesehatan Reproduksi adalah keadaan sehat yang menyeluruh, meliputi aspek fisik, mental dan sosial dan bukan sekedar tidak adanya penyakit atau gangguan segala hal yang ebrkaitan dengan sistem reproduksi, fungsinya maupun proses reproduksi itu sendiri. $^{2}$

Upaya pentingnya menumbuhkembangkan kesadaran akan pentingnya kesehatan reproduksi remaja di Indonesia karena anak-anak muda adalah orangtua dimasa depan. Keputusan kesehatan reproduksi dan seksual yang mereka buat hari ini akan mempengaruhi kesehatan dan kesejahteraan komunitas dan negara selama beberapa dekade mendatang. Pemuda akan menjadi pelaku utama pembangunan dan merupakan potensi yang harus dipersiapkan untuk menghadapi bonus demografi.

Gambaran kemajuan lambat pada Kesehatan Reproduksi Seksual Remaja diantaranya yaitu (1) Menstruasi masih dianggap sebagai topik yang tabu, (2) kematian terkait HIV AIDS tidak menurun dan terbatasnya data yang tersedia, (3) Tingkat Infeksi menular seksual tinggi, (4) Proporsi yang tinggi dari proporsi remaja perempuantelah mengalami kekerasan pasangan intim secara fisik dan/ atau seksual, (5) kurangnya data yang baik tentang tingkat aborsi tang tidak aman di kalangan remaja, dan resiko kematian dan kesakitan akibatnya, dan (6) Remaja masih diharapkan untuk menyesuaikan diri dengan norma gender tertentu. ${ }^{3}$

Pemerintah

telah mempersiapkan beberapa hal yakni (1). Peningkatan pendidikan (pengetahuan dan ketrampilan), (2) perlindungan terhadap kekerasan, diskriminasi dan eksploitasi, (3) Jaminan kesehatan mental dan fisik (termasuk informasi dan konseling kesehatan reproduksi remaja dan (4) penyediaan ruang publik sebagai wadah ekspresi diri.

Masa Remaja sebagai titik awal proses reproduksi menunjukkan persiapan strategi interfrensi perlu dimulai jauh sebelum masa usia subur. Nilai anak perempuan dan laki-laki dalam keluarga dan masyarakat, dan bagaimana perlakuan yang mereka terima merupakan faktor penting yang turut menentukan kesehatan reproduksi mereka dimasa datang. Menurut Robert Havinghurst dan sarlito, seorang remaja dalam menghadapi tugas-tugas perkembangan sehubungan dengan perubahanperubahan fisik dan peran sosial yang sedang terjadi pada dirinya, tugastugas itu adalah menerima kondisi fisiknya yang berubah. ${ }^{4}$

Dewasa ini permasalahan tentang kesehatan reproduksi seksual remaja Indonesia sangat beragam. Hasil survey menerangkan bahwa sebanyak $8 \%$ anak laki-laki dan $2 \%$ anak perempuan telah melakukan hubungan seksual pra nikah. Sebanyak $16 \%$ anak perempuan berusia 15-19 tahun mengalami kehamilan yang tidak diinginkan, 8\% diantaranya berusia 20-24 tahun, sebanyak $23 \%$ anak perempuan dan $19 \%$ anak laki-laki tahu apakah teman mereka telah melakukan 
aborsi dan 1\% dari mereka menemaninya selama proses tersebut, $45 \%$ anak perempuan dan $44 \%$ anak laki-laki mulai berkencan pada usia 15-17 tahun, sebanyak $15 \%$ remaja laki-laki dan 15 berusia 15-24 tahun pernah mengkonsumsi alkohol serta $5 \%$ pria dan $<1 \%$ wanita menggunakan obat-obatan terlarang.

Sekolah menjadi salah satu lingkungan tempat untuk mentransformasikan nilai dan pengetahuan. Keberadaan sekolah menjadi sebuah keharusan. Sekolah harus mampu di design untuk menciptakan generasi yang cerdas dan bermoral. Pendidikan seks sebagai salah satu alternatif dalam menanggulangi degradasi moral yang wajib menjadi perhatian. ${ }^{5}$

Pendidikan

Kesehatan

Reproduksi dan Seksual yang diberikan didalam pendidikan formal, akan mampu membentuk pemahaman yang baik dan terstruktur serta berkelanjutan kepada siswa khususnya usia remaja. Pengajar akan memberikan beberapa referensi

Kegiatan Pengabdian kepada masyarakat ini bertujuan untuk meningkatkan pengetahuan remja tentang pendidikan kesehatan reproduksi dan seksual pada usia remaja.

\section{Metode}

Lokasi pendidikan kesehatan yakni di Lembaga Kursus dan Pelatihan Sukma Medika Kabupaten Pekalongan. Peserta diberikan pemahaman terlebih dahulu melalui tujuan penyampaian materi pentingnya kesehatan reproduksi dan seksual paada remaja.

Metode yang diterapkan dalam pendidikan kesehatan pada kegiatan pengabdian kepada masyarakat ini yakni (1) Sosialisasi dan Perijinan, (2) Melakukan Affirmasi dan Pre Test (3) Melakukan Pendidikan kesehatan tentan Kesehatan Reproduksi dan Seksual (4) Evaluasi hasil kegiatan pendidikan kesehatan dengan Pre Test.

\section{Hasil dan Pembahasan}

Pendidikan kesehatan yang dilaksanakan di Lembaga Kursus dan Pelatihan Sukma Medika Kabupaten Pekalongan dapat meningkatkan pengetahuan dan pemahaman peserta yang sebelumnya tidak paham tentang pentingnya kesehatan reproduksi dan kesehatan seksual. Melalui pendidikan kesehatan yang telah dilaksanakan, diharapkan peserta dapat lebih memahami dan peduli akan kesehatan reproduksi dan seksualnya. Serta dapat memberikan pemahaman ytang benar tentang pola fikir kesehatan reproduksi dan seksual dengan benar sehingga dapat menjaga kesehatan dan terhindar dari resiko seks bebas.

Remaja merupakan generasi penerus bangsa, yang memiliki potensi besar untuk pembangunan Indonesia di masa mendatang. Kesehatan Reproduksi dan seksual perlu ditangani secara khusus dengan cara-cara yang ditunjukkan untuk menyiapkan remaja (yang kelak menjadi orangtua) yang bertanggungjawab. Masalah kesehatan reproduksi dan seksual adalah isu-isu seksual remaja, termasuk kehamilan yang tidak diinginkan, aborsi tidak aman, penyaki menular melalui seks, dan HIV/AIDS, dilakukan pendekatan melalui promosi perilaku seksual yang bertanggungjawab dan reproduksi sehat, termasuk disiplin pribadi yang mandiri serta dukungan pelayanan yang layak dan konseling yang sesuai secara spesifik untuk umur mereka. ${ }^{6}$

Peserta kegiatan upaya peningkatan pengetahuan tentang 
pendidikan kesehatan reproduksi dan seksual menunjukkan antusiasme yang baik selama proses pendidikan kesehatan. Antusiasme tersebut ditunjukkan dengan respon peserta yang sangat baik serta kemauan peserta untuk bertanya dan menguraikan pendapatnya. Hasil pendidikan kesehatan ini diharapkan dapat meningkatkan pengetahuan serta pemahaman peserta tentang pentingnya kesehatan reproduksi dan kesehatan seksual pada remaja. Hal ini ditunjukkan dengan hasil kuesioner pre dan post test yang menunjukkan adanya peningkatan pengetahuan tentang pendidikan kesehatan reproduksi dan seksual pada remaja di Lembaga Kursus dan Pelatihan Sukma Medika Kabupaten Pekalongan. (Grafik.1.1)

Grafik 1.1 Hasil Pre Test dan Post Test ( Evaluasi)

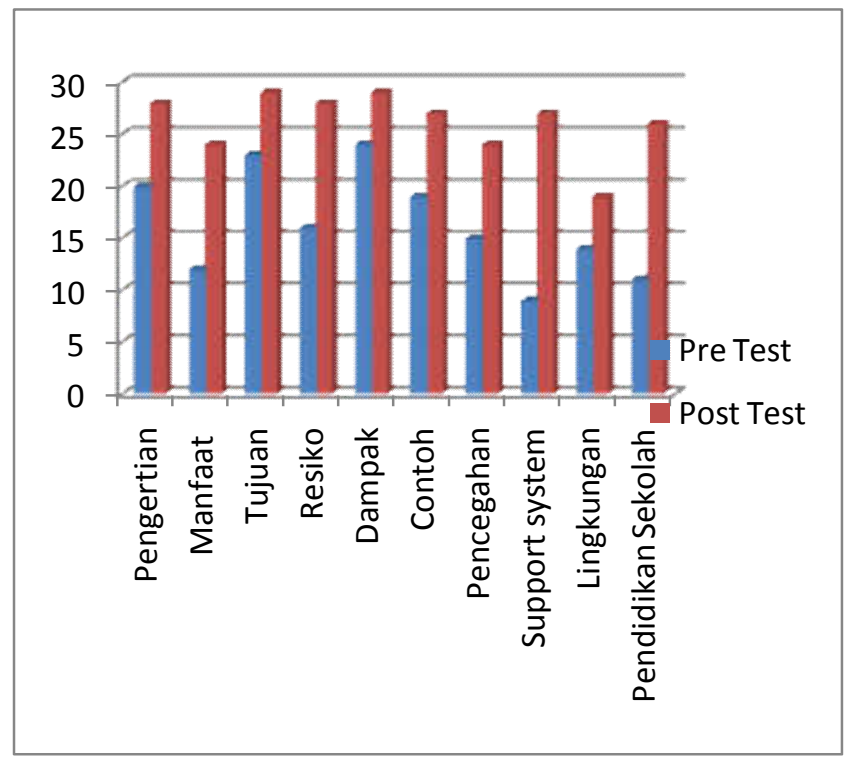

\section{Kesimpulan}

Pendidikan Kesehatan ini dapat meningkatkan pengetahuan dan pemahaman peserta tentang pentingnya kesehatan reproduksi dan seksual pada remaja, sehingga dapat menjaga kesehatan reproduksinya dan terhindar dari penyimpangan seksual dan seks bebas.

\section{Daftar Pustaka}

[1] Departemen Kesehatan RI. Undang-Undang Republik Indonesia Nomor 36 Tahun 2009. Jakarta.

[2] Made Okara Negara. Mengurang Persoalan Kehidupan Seksual dan Reproduksi Perempuan dalam Jurnal Perempuan Cetakan No. 41. Jakarta: Yayasan Jurnal Perempuan, 2005.

[3] WHO. Dunia yang berubah dari kesehatan dan hak seksual dan reproduksi remaja, 2020.

[4] Sarlito Wirawan Sarwono, Psikologi Remaja; Jakarta: Raja Grafindo Persada, 2001.

[5] Abu, Ahmadi dan Nur Uhbiyati. Ilmu Pendidikan. Jakarta: Rineka Cipta, 2001.

[6] Layyin Mahfina, Elfi Yuliani, Retno Widyaningrum, Remaja dan Kesehatan Reproduksi. Yogyakarta: STAIN Ponorogo, 2009. 